\title{
Teacher Performance, Parent's Role, and Student Learning Outcomes in Muhammadiyah Junior High School
}

\author{
Sitti Nur Suraya Ishak, Suyatno* \\ Department of Educational Management, Faculty of Teacher Training and Education, Universitas Ahmad Dahlan, Indonesia
}

Received November 29, 2019; Revised January 6, 2020; Accepted January 13, 2020

Copyright $\bigcirc 2020$ by authors, all rights reserved. Authors agree that this article remains permanently open access under the terms of the Creative Commons Attribution License 4.0 International License

\begin{abstract}
The purpose of this research was to determine the effects of teacher performance and the role of parents toward student learning outcomes of Indonesian Language, Mathematics, English, and Natural Sciences in the grade 8 of Muhammadiyah 8 Junior High School Yogyakarta. This was a quantitative research with ex post facto approach. The research sample was 98 grade 8 students taken by simple random sampling technique. Data collection techniques was by questionnaires and documentation. The collected data were analyzed with descriptive analysis and hypothesis testing with Generalized Linear Model (GLZ). The results showed that (1) teacher performance significantly affect Indonesian Language learning outcome by $0,046 / 4,6 \%$ of Beta value; The role of parents also significantly affect Indonesian Language learning outcome by $0,040 / 4,0 \%$ of Beta value; (2) teacher performance affect Mathematics learning outcome by $0,020 / 2,0 \%$ of Beta value; the role of parents insignificantly affect Mathematics learning outcome by $0,001 / 0,1 \%$ of Beta value; (3) teacher performance insignificantly affect English Language learning outcome by $0,005 / 0,5 \%$ of Beta value; the role of parents significantly affect English Language learning outcome by $0,073 / 7,3 \%$ of Beta value; (4) teacher performance insignificantly affect Natural Sciences learning outcome by $0,000 / 0 \%$ of Beta value; the role of parents significantly affect Natural Sciences learning outcome by $0,028 / 2,8 \%$ of Beta value; The results of this research reaffirm the importance of the family' role as part of the tri-center of education (school, family, and community) which is a characteristic of Indonesia education. The family environment has an important role in improving student achievement in school.
\end{abstract}

Keywords Teacher Performance, Role of Parents, Student Learning Outcomes, Muhammadiyah School

\section{Introduction}

Youth and Sports Affairs Agency of Yogyakarta Special Region (2019) stated that the criteria for the Competency Achievement of Graduates Based on National Examination Results are determined nationally, and National Examination results are reported in the range of 0 (zero) to 100 (one hundred) and categorized as in the table 1.

Table 1. Criteria for the Competency Achievement of Graduates

\begin{tabular}{|c|c|}
\hline Score Range & Category \\
\hline$\geq 85-100$ & Very Good \\
\hline$\geq 70-85$ & Good \\
\hline$\geq 55-70$ & Sufficient \\
\hline$\leq 55$ & Poor \\
\hline
\end{tabular}

Researchers found that student learning outcomes in Yogyakarta are still relatively low. From the four subjects tested in the National Examination, only Indonesian Language subject classified as good with an average score of 74,79 while the three other subjects, Mathematics, Natural Sciences and English Language, were still low. The average scores for national examination in the 2017/2018 school year can be seen in the figure 1 .

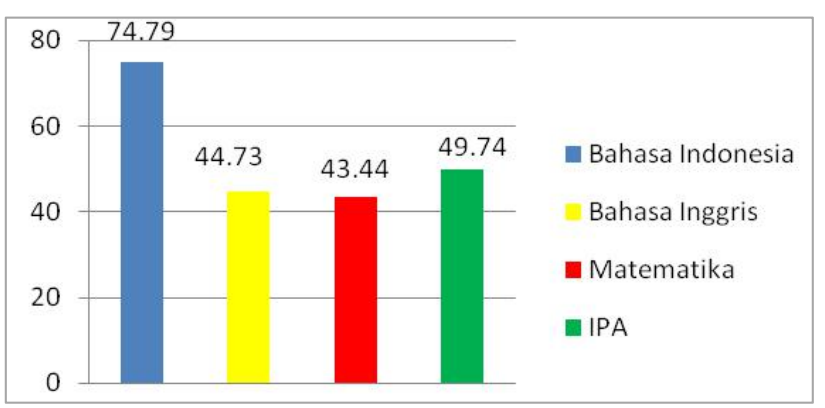

Figure 1. The average score of National Examination of Muhammadiyah 8 Junior High SchoolYogyakarta 
Based on the data in Figure 1, the scores of Indonesian Language subject are in the good category, while the scores of English Language, Mathematics, and Natural Sciences subjects are in the poor category.

Based on the preliminary study, the researchers found that students did not like Mathematics (Heyder et al., 2020), Natural Sciences, and English Language subjects because the students considered it as difficult. Also, the unpleasant teaching method made students uninterested and unmotivated to learn (Yigzaw, 2019).

Students' success in learning is affected by many factors. Purwanto (2003) stated that there are two factors affecting learning outcomes, the first is physiological factors in the form of physical conditions and five senses and psychological factors in the form of talent, interest, intelligence, and motivation; second is environmental factors in the form of natural and social environment and instrumental factors in the form of curriculum, teaching materials, teachers, facilities, administration, and management. Hamalik (2002) also suggested that there are two main factors that affecting learning which are heredity and the environment. Syah (2003) also added a third factor, which is learning approach or strategy. Based on those opinion, physiological factors, environment, and learning approaches can affect student learning outcomes.

The education quality, which is assessed from student achievement, is highly determined by the teachers (Supardi, 2014). Teacher work load standard refers to Law No. 14 of 2005 concerning Teachers and Lecturers article 35 stated that the main work load of teachers is planning learning, implementing learning, assessing learning outcomes, guiding, training students, and carrying out additional tasks. Based on the discussions with Vice Principal of Curriculum section in Muhammadiyah 8 Junior High School Yogyakarta revealed that teachers have some obstacles in making learning plan, thus they are unoptimal in delivering learning material (the results of interview with the teacher). In addition, the teachers also have obstacles in planning the assessment of student learning outcomes. Teachers also do not arouse students' interest in subjects they have taught such as Mathematics, Natural Sciences, and English Language (the results of interview with the teacher). Furthermore, the very large administrative burden makes their performance in the classroom un-optimal. Other than that, the excessive variation in methods makes students unable to grasp the lesson's essence.

According to Regulation of the Minister of Education and Culture of the Republic of Indonesia number 30 of 2017 article 1, family involvement is a family participation form in the education implementation to realize the ideals of the national education (Menteri Pendidikan dan Kebudayaan Republik Indonesia, 2017). No less influential, even parents or families must participate in the education world. Parental traits, family management practices, family tensions, and home circumstances can have good or bad effects on learning activities and student learning outcomes (Syah,
2003). Therefore, assistance from the environment, such as teachers and parents, is very important to shape the children's learning atmosphere (Hamalik, 2002). Based on a preliminary study, the researchers found that parents still lacked attention to their children's learning due to the their workload. Therefore, parents lack of time to guide children to do homework and help children's learning difficulties. However, parents have other initiatives such as holding tutoring program for children (Interview with Vice Principal of Curriculum section in Muhammadiyah 8 Junior High School Yogyakarta).

Researches that studied similar variables has been done by several researchers. Yang (2017) research showed that there are similarities between parents who play a key role in shaping social condition at home and teachers who play an important role in building school social capital such as collective school norms that affect student academic achievement. Tataroğlu-Taşdan (2019) research revealed that teachers mostly using mathematical descriptions in their teaching followed by mathematical explanations and justifications. However, there are some deficiencies in the teachers' mathematics knowledge for teaching. Bashir (2014) investigated the effect of environment toward junior high school student Mathematic learning outcome in the Nigeria's three north western states of Kebbi, Sokoto, and Zamfara. It was a survey research and the sample was 1000 students. Data collection was done by questionnaire. Hypothesis testing was done by Chi-square. The findings showed that from students' views, the school environment has a bigger effect on student Mathematic performance than the home environment. The students' home environment has no influence on student Mathematic performance. Yigzaw (2019) aimed to investigate the role of parents in shaping students' behavior. Forty teachers were selected through the census survey method for the questionnaire and 10 parents were selected for the interview. The study revealed that the parent low contribution in improving students school behavior is due to the lack of proper training strategies and poor interactions between home and school. This study showed that the cause of indiscipline are improper rules and regulations, negative relationships between students and teachers, school administrators' lack of continuous monitoring and evaluation, poor teaching methods, inadequate school facilities, un-optimal parental monitoring, and school administrators.

In their research, Junianto \& Wagiran (2013) showed the effect of teacher teaching performance, parent involvement, self-actualization, and achievement motivation to student learning outcomes, they are respectively 0,145 or a percentage of $14,5 \% ; 0,128$ or $12,8 \% ; 0,108$ or $10,8 \%$; and 0,098 or $9,8 \%$. This shows that the teacher teaching performance and parent involvement have an effect on student learning outcomes improvement. Wahyuni (2017) stated that there is a correlation between the role of parents and student achievement. Astuti and Rivaie (2013) stated that 1) parents actions in guiding children's learning are still 
un-optimal, 2) obstacle faced by parents in educating children at home is their work load so they do not have time, also economy factor resulted in parents cannot provide learning facilities, 3) parents' effort in overcoming obstacles when guiding children is that they are trying to take the time to supervise children and provide guidance to the children. Rafsanjani (2016) said that self-concept in the academic field has significant functions as a mediator variable on the perceptions effect of parental involvement on student learning outcomes. Lestari (2016) revealed that teacher teaching performance has a significant effect on student learning achievement by $53 \%$. Wahyudi, Kuncoro, and Dardiri (2018) research showed that pedagogical performance, environmental conditions, and learning outcomes are considered good. Hypothesis test results indicated that simultaneously there is a significant effect of pedagogical performance, learning environment, and work interest toward student learning outcomes. Narwoto (2014) explained that 1) there is a significant effect of teacher teaching performance, utilization of learning facilities, and motivation to excel toward vocational theory learning achievement by $32,8 \%, 9 \%$, and $14,1 \%$, and there is also a significant effect of teacher teaching performance, utilization of learning facilities, and student motivation to excel toward learning achievement by $34,3 \%$.

Based on the background, the research questions are:

1) How much effect does the teacher performance and the role of parents have toward Indonesian Language learning outcome?

2) How much effect does the teacher performance and the role of parents have toward Mathematics learning outcome?

3) How much effect does the teacher performance and the role of parents have toward English Language learning outcome?

4) How much effect does the teacher performance and the role of parents have toward Natural Sciences learning outcome?

\section{Literature Review}

\subsection{Teacher Performance}

Performance is the achievement, demonstrated accomplishment, or work ability. Junianto and Wagiran (2013) said that performance is the individuals abilities to do a certain jobs that being assessed and measured based on established standards. Therefore, it is concluded that performance is working demonstration carried out according to the existing procedures.

According to Law No. 14 of 2005, teacher is a professional educator with the main task of educating, teaching, guiding, directing, training, assessing, and evaluating. Quality learning can be realized by teachers who have high ability and high work motivation (Suyatno et al, 2019a). Through quality learning, it will also produce quality graduates (Supardi, 2014).Teachers are the key actor in the classroom. Teachers are in control of learning activities in the classroom. Teachers are the people who interacts the most with students. Teachers have big influence on students (Hamalik, 2002). Syah (2003) stated that caring teachers who able to set good examples and also diligent in learning, such as reading and sharing, will be a booster for children to study harder.

Teacher performance is the teachers' abilities to carry out learning tasks in schools and take responsibility for students under their guidance by increasing student learning achievement. Therefore, teachers determine the education quality, the success or failure of the learning process, and whether or not the educational and learning objectives are achieved (Supardi, 2014). Teacher performance can be seen from the required competencies that have been fulfilled. It is the pedagogical competence, personality competence, social competence, and professional competence. Teacher work load standards refer to Law No. 14 of 2005 concerning Teachers and Lecturers article 35 stated that the teachers work load includes the main activities namely planning learning, implementing learning, assessing learning outcomes, guiding and training students, and carrying out additional tasks (Supardi, 2014). Teachers main tasks are planning, implementing, evaluating, and guiding the teaching and learning activities (Makmun, 2001).

Dimyati (2013) revealed that in planning learning, teachers must understand the learning principles. In carrying out learning, knowledge of the learning theories and principles can help teachers choose the right action. With learning theories and principles, the teachers can develop ways to improve student learning. Wahyudi et al. (2018) showed that $76,60 \%$ of student learning outcomes are influenced by teacher performance, which is $32,43 \%$ teachers ability to teach, 32,38\% mastery of learning material, and $8,60 \%$ teacher attitudes toward subjects.

According to Tataroglu-Tasdan (2019) in order to achieve effective teaching, mathematics teachers need to have a variety of knowledge and skills. It is important for teachers to design and use accurate mathematical descriptions, explanations, and justifications so that they can be understood and useful for students in the contexts that reflect the teachers' Mathematical knowledge when teaching. Nyikahadzoyi (2015) suggested that secondary school teachers must understand different introductions for a particular topic, the practice order, explanations, representations, definitions, and examples.

\subsection{The Role of Parents}

Wahyuni (2017) said that children are born within the parents care and raised in families. Parents work as care givers, mentors, carers, and educators in the family. Parents play a role in giving authority to children to determine their 
interests, talents and other skills, provide learning facilities, and help their learning difficulties. Furthermore, Schaefer (2007) stated that the children good learning outcomes depend on the parents' way of teaching at home, because parents are the first educators for their children.

Students' parents and families must participate in the student education, especially in the learning activities. Parental traits, family management practices, family tensions, and home circumstances can have good or bad effects on learning activities and student learning outcomes (Syah, 2003). Therefore, assistance from the environment, such as teachers and parents is very important to shape the children learning atmosphere (Hamalik, 2002). Based on the description, it can be concluded that schools must work together with parents concerning students learning so that school goals can be achieved, thus can produce bonafide graduates or outputs.

Experts from the National Institute of Child Health and Human Development (NICHD) offered a trusted and proven approach on how to successfully act as a good parent. This approach is known as RPM3. RPM3 stands for responding, preventing, monitoring, mentoring, and modeling (Adhim, 2004). The role of parents are as follows. First is responding that means parents responding to children appropriately, buying books as needed, together making rules about learning, sleeping at night, and watching TV. Second is preventing, parents preventing the behaviors problem in children. Third is monitoring, parents supervise children interaction with their social environment and monitor children's academics. Fourth is mentoring, which is parents helping with children homework/assignments, giving examples in learning, encouraging the habits of reading, writing, and discussion. Fifth is modeling, parents set as the role model for children, attend meetings with teachers, and volunteer at school.

Cooper and Maloof (1999) stated that parents must helping their children with their homework, asking questions related to language classes, and even make an effort to learn languages together with children. Xuesong (2006) suggested that parents must involve themselves in the process of children's foreign language learning by training children to be a good language learners, and also parents must create language learning opportunities for their children outside the classroom by acting as teacher collaborators and language learning facilitator. Furthermore, aside for teachers', parents'role in increasing the motivation level to learn foreign languages in junior high school students should not be underestimated (Coskun, 2016). Nihat (2012) suggested that parents should support children's personalities and communicate effectively. It is recommended that parents follow the children development in an on going collaboration with teachers (Erdem \& Şimşek, 2009).

The parents involvement in the students learning process has a positive effect toward academic success (Nihat, 2012). Xuesong (2006) claimed that families can influence the students' foreign languages learning both directly by training them to become a good language learners and indirectly by acting as language learning facilitators and teacher collaborators. Parents can show their positive attitude toward learning foreign languages by playing an active role in the students' learning process both at home and at school (Rosenbusch, 1987). Cooper and Maloof (1999) stated that students adopt a more positive attitude toward language learning when their parents asking questions about their foreign language lessons, helping their assignments, and trying to learn languages together with them. Epstein (2010) showed that parents can communicate and collaborate with schools and help their children at home to learn and participate in decisions at school.

The parents involvement plays an important role in determining the education system success. Schools must consider the parents and the community's active involvement. Students with parents who involve in school tend to have better academic results than students whose parents not involved in school (Yigzaw, 2019). Parents participation in school can often improve children's self-esteem and academic achievement, improve parent-children relationships, and help parents develop positive attitudes toward school, and better understanding of the school process (Yigzaw, 2019).

\subsection{Student Learning Outcomes}

According to Dimyati (2013), learning outcomes are values that are achieved, in the form of numbers, letters, or symbols, after being tested at the end of each learning. Learning outcomes are the learning activities achievements that have been carried out between teachers and students in the form of written measurements and assessments (Wahyudi, Kuncoro, \& Dardiri, 2018). Hamalik (2002) also suggested that learning outcomes are behavior changes in learners that can be seen and measured in the form of knowledge, attitudes, and skills. Winkel (1999) defined learning outcomes as changes in human behavior and attitudes. Sudjana (2014) defined student learning outcomes as changes in learner attitude patterns. Learning outcomes are often used as a measurement to know the mastery of the material that has been taught (Purwanto, 2011). The measured learning outcomes are a reflection of the teaching objectives (Gronlund et al., 1985). Based on the those theories, it is concluded that student learning outcomes are student acquisition in the form of grades and behavior changes as an effect of the increasing cognitive, affective, and psychomotor abilities.

Learning outcomes evaluation is an activity to determine whether the learning objectives have been achieved (Wahyudi et al., 2018). Furthermore, Sudjana (2014) stated that the assessment of learning outcomes involves short-term learning outcomes and long-term learning outcomes. The assessment is carried out to obtain accurate information about the success of student learning, teachers, 
and the learning process itself. Therefore, decisions can be made about learning, student difficulties, and the guidance efforts needed (Wahyudi et al., 2018). Furthermore, Siregar (2015) stated that the learning assessment is a measurement of learning outcomes for the decision making process about student learning success. Learning activities carried out are said to be efficient when students are able to achieve maximum learning outcomes as revealed by Syah (2003) that learning activities are efficient when the learning efforts can produce high achievements.

\section{Materials and Methods}

This research method was quantitative with ex post facto approach. The reason for choosing this method because it was in accordance with the research objectives, which was to determine the contribution of the teacher performance and the role of parents variables toward student learning outcomes in the Indonesian Language, Mathematics, English Language, and Natural Sciences subjects. The research population was all grade 8 students as many as 117 students. Determination of the number of samples was based on the Slovin formula as follows: $n=N / 1+n(0,05)^{2}$. Samples/subjects were 98 students taken by simple random sampling technique. Data collection techniques was by questionnaires and documentation. The questionnaire was by the Likert scale. It was developed by researchers based on the framework instrument that has been made. It consists of two types namely teacher performance questionnaire and the role of parents questionnaire. The questionnaire was validated through a field test towards 32 students in the 8th grade. After that, the questionnaire was processed using the product moment correlation formula. Teacher performance questionnaire instrument consisted of 35 statements. Through the validity test, 25 items wre declared valid and 10 items were invalid. The parent's role questionnaire instrument consisted of 36 statements and through the validity test, 24 statements were declared valid and 12 items were invalid.Teacher performance questionnaire consisted of 25 statements and the role of parents questionnaire consisted of 24 statements. The reliability test was calculated by the Alpha formula. It was obtained the results of the teacher performance reliability test as follows:

Table 2. Reliability test of teacher performance

\begin{tabular}{|c|c|c|}
\hline Alpha & r table & Information \\
\hline 0,836 & 0,3388 & Reliable \\
\hline
\end{tabular}

The reliability test results of the parent's role are as follows:

Table 3. Reliability test of parent's role

\begin{tabular}{|c|c|c|}
\hline Alpha & r table & Information \\
\hline 0,844 & 0,3388 & Reliable \\
\hline
\end{tabular}

The documentation was used to collect data on students' final examination scores. Data analysis techniques was by descriptive analysis. This analysis showed the number of subjects in the group, the mean of the questionnaire scores, standard deviation of questionnaire scores, maximum scores, minimum scores, and histograms (Hendrawati \& Prasojo, 2015). Hypothesis testing was by Generalized Linear Model (GLZ), which is a form of generalization of the General Linear Model (GLM) contained in SPSS. GLZ does not follow normality assumptions like GLM. General Linear Model (GLM) is a multivariate analysis technique of independent variables with more than 1 variable depend on the interval scale and normally distributed. While the GLZ allows dependent variables not to have normal distribution (Sarwono, 2014).

\section{Results}

\subsection{Teacher Performance}

Table 4. The description of teacher performance

\begin{tabular}{|c|c|c|}
\hline & Statistics & Std. Error \\
\hline Mean & 91.50 & 1.243 \\
\hline Median & 92.00 & \\
\hline Variance & 151.490 & \\
\hline Std. Deviation & 12.308 & \\
\hline Minimum & 48 & \\
\hline Maximum & 123 & \\
\hline Range & 75 & \\
\hline
\end{tabular}

Based on the data, it is known that the lowest score is 48 and the highest score is 123 . The mean is 91,50 , the median is 92,00 , and the standard deviation is 12,308 . The data can be seen in the categorization of teacher performance scores in table 5 .

Table 5. Categorization of teacher performance

\begin{tabular}{|c|c|c|c|c|c|}
\hline & & Frequency & Percent & $\begin{array}{c}\text { Valid } \\
\text { Percent }\end{array}$ & $\begin{array}{c}\text { Cumulative } \\
\text { Percent }\end{array}$ \\
\hline \multirow{7}{*}{ Valid } & $<73$ & 7 & 7.1 & 7.1 & 7.1 \\
\cline { 2 - 6 } & $73-85$ & 20 & 20.4 & 20.4 & 27.6 \\
\cline { 2 - 6 } & $85-98$ & 44 & 44.9 & 44.9 & 72.4 \\
\cline { 2 - 6 } & $98-110$ & 24 & 24.5 & 24.5 & 96.9 \\
\cline { 2 - 6 } & $>110$ & 3 & 3.1 & 3.1 & 100.0 \\
\cline { 2 - 6 } & Total & 98 & 100.0 & 100.0 & \\
\hline
\end{tabular}

The categorization of teacher performance scores table shows that the respondents answer of $3,1 \%$ is in the very high category, while $24,5 \%$ of response is in high category, $44,9 \%$ is in the moderate category, $20,4 \%$ is in low category, and $7,1 \%$ is in the very low category. Therefore, the biggest categorization of teacher performance is at a moderate level. 


\subsection{The Role of Parents}

Table 6. Description of the role of parents

\begin{tabular}{|c|c|c|}
\hline & Statistics & Std. Error \\
\hline Mean & 90.40 & 1.233 \\
\hline Median & 90.50 & \\
\hline Variance & 149.005 & \\
\hline Std. Deviation & 12.207 & \\
\hline Minimum & 54 & \\
\hline Maximum & 117 & \\
\hline Range & 63 & \\
\hline
\end{tabular}

Based on the data, it is known that the lowest score is 54 and the highest score is 117 . The mean is 90,40, the median is 90,50 , and the standard deviation is 12,207 . The data can be seen in table 6 .

Table 7. Categorization of the role of parents

\begin{tabular}{|c|c|c|c|c|c|}
\hline \multirow{7}{*}{ Valid } & $<72$ & 8 & 8.2 & 8.2 & 8.2 \\
\hline & $72-84$ & 20 & 20.4 & 20.4 & 28.6 \\
\cline { 2 - 6 } & $84-96$ & 39 & 39.8 & 39.8 & 68.4 \\
\cline { 2 - 6 } & $96-109$ & 26 & 26.5 & 26.5 & 94.9 \\
\cline { 2 - 6 } & $>109$ & 5 & 5.1 & 5.1 & 100.0 \\
\cline { 2 - 6 } & Total & 98 & 100.0 & 100.0 & \\
\hline
\end{tabular}

The categorization of the role of parents scores table shows that the answers from respondents are 5,1\% is in the very high category, while $26,5 \%$ response is in high category, $39,8 \%$ is in moderate category, $20,4 \%$ is in the low category, and $8,2 \%$ is in the very low category. Therefore, the biggest categorization of role of parents is at a moderate level.

\subsection{Indonesian Language}

Table 8. The Description of Indonesian Language scores

\begin{tabular}{|c|c|c|}
\hline & Statistic & Std. Error \\
\hline Mean & 78.62 & .416 \\
\hline Median & 78.00 & \\
\hline Variance & 16.959 & \\
\hline Std. Deviation & 4.118 & \\
\hline Minimum & 69 & \\
\hline Maximum & 88 & \\
\hline Range & 19 & \\
\hline
\end{tabular}

Based on the data, it is known that the lowest score is 69 and the highest score is 88 . The mean is 78,62 , the median is 78,00 , and the standard deviation is 4,118 . The data can be seen in table 8 .

Table 9. Categorization of Indonesian Language score

\begin{tabular}{|c|c|c|c|c|}
\hline & Frequency & Percent & $\begin{array}{c}\text { Valid } \\
\text { Percent }\end{array}$ & $\begin{array}{c}\text { Cumulative } \\
\text { Percent }\end{array}$ \\
\hline \multirow{7}{*}{ Valid } & 7 & 7.1 & 7.1 & 7.1 \\
\cline { 2 - 5 } & 17 & 17.3 & 17.3 & 24.5 \\
\cline { 2 - 5 } & 49 & 50.0 & 50.0 & 74.5 \\
\cline { 2 - 5 } & 22 & 22.4 & 22.4 & 96.9 \\
\cline { 2 - 5 } & 3 & 3.1 & 3.1 & 100.0 \\
\cline { 2 - 5 } & 98 & 100.0 & 100.0 & \\
\hline
\end{tabular}

The categorization of Indonesian Language scores table shows that $31 \%$ is in the very high category, $22,4 \%$ is categorized as high, $50,0 \%$ is moderate, $17,3 \%$ is low, and $7,1 \%$ is very low. Based on the table, the biggest score of Indonesian Language is at a moderate level.

\subsection{Mathematics}

Table 10. Description of Mathematics scores

\begin{tabular}{|c|c|c|}
\hline & Statistic & Std. Error \\
\hline Mean & 71.42 & .234 \\
\hline Median & 71.00 & \\
\hline Variance & 5.359 & \\
\hline Std. Deviation & 2.315 & \\
\hline Minimum & 68 & \\
\hline Maximum & 81 & \\
\hline Range & 13 & \\
\hline
\end{tabular}

Based on the data, it is known that the lowest score is 68 and the highest score is 81 . The mean is 71,42 , the median is 71,00 , and the standard deviation is 2,315 . An overview of the data can be seen in table 10 .

Table 11. Categorization of Mathematics scores

\begin{tabular}{|c|c|c|c|c|c|}
\hline & Frequency & Percent & $\begin{array}{c}\text { Valid } \\
\text { Percent }\end{array}$ & $\begin{array}{c}\text { Cumulative } \\
\text { Percent }\end{array}$ \\
\hline \multirow{7}{*}{ Valid } & $<68$ & 3 & 3.1 & 3.1 & 3.1 \\
\cline { 2 - 6 } & $68-70$ & 42 & 42.9 & 42.9 & 45.9 \\
\cline { 2 - 6 } & $70-72$ & 35 & 35.7 & 35.7 & 81.6 \\
\cline { 2 - 6 } & $72-75$ & 13 & 13.3 & 13.3 & 94.9 \\
\cline { 2 - 6 } & $>75$ & 5 & 5.1 & 5.1 & 100.0 \\
\cline { 2 - 6 } & Total & 98 & 100.0 & 100.0 & \\
\hline
\end{tabular}

The categorization of Mathematics scores table shows that $5,1 \%$ is categorized as very high, $13,3 \%$ response is categorized as high, $35,7 \%$ is categorized as moderate, $42,9 \%$ is categorized as low and $3,1 \%$ is categorized as very 
low. Therefore, the biggest mathematics score is at the low level. The score categorization is presented in table 11 .

\subsection{English Language}

Table 12. Description of English Language scores

\begin{tabular}{|c|c|c|}
\hline & Statistic & Std. Error \\
\hline Mean & 74.8061 & .62987 \\
\hline Median & 73.0000 & \\
\hline Variance & 38.880 & \\
\hline Std. Deviation & 6.23535 & \\
\hline Minimum & 61.00 & \\
\hline Maximum & 94.00 & \\
\hline Range & 33.00 & \\
\hline
\end{tabular}

Based on the data, it is known that the lowest score is 61 and the highest score is 94 . The mean is 74,81 , the median is 73,00 , and the standard deviation is 6,235 . The data can be seen in table 12 .

Table 13. The Categorization of English Language scores

\begin{tabular}{|c|c|c|c|c|c|}
\hline & & Frequency & Percent & $\begin{array}{c}\text { Valid } \\
\text { Percent }\end{array}$ & $\begin{array}{c}\text { Cumulative } \\
\text { Percent }\end{array}$ \\
\hline \multirow{7}{*}{ Valid } & $<65$ & 3 & 3.1 & 3.1 & 3.1 \\
\cline { 2 - 6 } & $65-72$ & 42 & 42.9 & 42.9 & 45.9 \\
\cline { 2 - 6 } & $72-78$ & 28 & 28.6 & 28.6 & 74.5 \\
\cline { 2 - 6 } & $78-84$ & 18 & 18.4 & 18.4 & 92.9 \\
\cline { 2 - 6 } & $>84$ & 7 & 7.1 & 7.1 & 100.0 \\
\cline { 2 - 6 } & Total & 98 & 100.0 & 100.0 & \\
\hline
\end{tabular}

The categorization of English Language table shows that $7,1 \%$ is very high, $18,4 \%$ is categorized as high, $28,6 \%$ is moderate, $42,9 \%$ is low and $3,1 \%$ is very low. Therefore, the biggest categorization of English Language scores is at the low level.

\subsection{Natural Science}

Table 14. Description of the Natural Sciences scores

\begin{tabular}{|c|c|c|}
\hline & Statistic & Std. Error \\
\hline Mean & 71.74 & .234 \\
\hline Median & 71.50 & \\
\hline Variance & 5.388 & \\
\hline Std. Deviation & 2.321 & \\
\hline Minimum & 68 & \\
\hline Maximum & 80 & \\
\hline Range & 12 & \\
\hline
\end{tabular}

Based on the data, it is known that the lowest score is 68 and the highest score is 80 . The mean is 71,74 , the median is 71,50 , and the standard deviation is 2,321 . The data description can be seen in the table 14 .

Table 15. The Categorization of Natural Sciences scores

\begin{tabular}{|c|c|c|c|c|c|}
\hline & & Frequency & Percent & $\begin{array}{c}\text { Valid } \\
\text { Percent }\end{array}$ & $\begin{array}{c}\text { Cumulative } \\
\text { Percent }\end{array}$ \\
\hline \multirow{7}{*}{ Valid } & $<68$ & 4 & 4.1 & 4.1 & 4,1 \\
\cline { 2 - 6 } & $68-71$ & 45 & 45.9 & 45.9 & 50.0 \\
\cline { 2 - 6 } & $71-73$ & 32 & 32.7 & 32.7 & 82.7 \\
\cline { 2 - 6 } & $73-75$ & 9 & 9.2 & 9.2 & 91.8 \\
\cline { 2 - 6 } & $>75$ & 8 & 8.2 & 8.2 & 100.0 \\
\cline { 2 - 6 } & Total & 98 & 100.0 & 100.0 & \\
\hline
\end{tabular}

The teacher performance score categorization table shows that $8,2 \%$ is categorized very high, $9,2 \%$ response is categorized as high, $32,7 \%$ is categorized as moderate, $45,9 \%$ is categorized as low, and $4,1 \%$ is categorized as very low. Therefore, the biggest Natural Sciences score categorization is at the moderate level.

\subsection{Hypothesis Test}

\subsection{Indonesian Language}

Table 16. Tests of Model Effects

\begin{tabular}{|c|c|c|c|}
\hline \multirow{2}{*}{ Source } & \multicolumn{3}{|c|}{ Type III } \\
\cline { 2 - 4 } & Wald Chi-Square & df & Sig. \\
\hline (Intercept) & 8224.955 & 1 & .000 \\
\hline $\mathrm{X} 1$ & 23.080 & 1 & .000 \\
\hline $\mathrm{X} 2$ & 16.903 & 1 & .000 \\
\hline
\end{tabular}

The value of the counted Chi-square 23,080 > Chi-square table 3,841 then $\mathrm{H} 0$ is rejected and $\mathrm{H} 1$ is accepted. This means that teacher performance covariate affect Indonesian Language learning outcome. The value of the counted Chi-square $16,903>$ Chi-square table 3,841 then $\mathrm{H} 0$ is rejected and $\mathrm{H} 1$ is accepted. This means that the role of parents covariate has an effect on Indonesian learning outcomes.

Table 17. Parameter Estimates

\begin{tabular}{|c|c|c|c|c|c|}
\hline \multirow{2}{*}{ Parameter } & \multirow{2}{*}{$\mathrm{B}$} & \multirow{2}{*}{$\begin{array}{c}\text { Std. } \\
\text { Error }\end{array}$} & & \multicolumn{3}{|c|}{ Hypothesis Test } \\
\cline { 4 - 6 } & & $\begin{array}{c}\text { Wald } \\
\text { Chi-Square }\end{array}$ & $\mathrm{df}$ & Sig. \\
\hline Intercept & 79.243 & .8738 & 8224.955 & 1 & .000 \\
\hline $\mathrm{X} 1$ & -.046 & .0096 & 23.080 & 1 & .000 \\
\hline $\mathrm{X} 2$ & .040 & .0097 & 16.903 & 1 & .000 \\
\hline
\end{tabular}

Based on the parameter test as shown in table 17, teacher performance covariate significantly affect Indonesian Language learning outcomes by Beta value of $-0,046$ or $4,6 \%$ because the value of sig $0,000<0,05$. The role of parents covariate significantly affect the Indonesian 
Language learning outcomes by Beta value of 0,040 or $4,0 \%$ because the value of sig $0,000<0,05$.

4.7.2. Mathematics

Table 18. Tests of Model Effects

\begin{tabular}{|c|c|c|c|}
\hline \multirow{2}{*}{ Source } & \multicolumn{3}{|c|}{ Type III } \\
\cline { 2 - 4 } & Wald Chi-Square & df & Sig. \\
\hline (Intercept) & 6327.390 & 1 & .000 \\
\hline $\mathrm{X} 1$ & 4.227 & 1 & .040 \\
\hline $\mathrm{X} 2$ & .017 & 1 & .896 \\
\hline
\end{tabular}

The value of the counted Chi-square 4,227 > Chi-square table 3,841 then $\mathrm{H} 0$ is rejected and $\mathrm{H} 1$ is accepted. This means that the teacher performance covariate affects the Mathematics learning outcomes. The value of the counted Chi-square $0,017<$ Chi-square table 3,841 then $\mathrm{H} 0$ is accepted and $\mathrm{H} 1$ is rejected. This means that the role of parents covariate has no effect on Mathematics learning outcomes.

Table 19. Parameter Estimates

\begin{tabular}{|c|c|c|c|c|c|}
\hline \multirow{2}{*}{ Parameter } & \multirow{2}{*}{$\mathrm{B}$} & \multirow{2}{*}{$\begin{array}{c}\text { Std. } \\
\text { Error }\end{array}$} & & \multicolumn{3}{|c|}{ Hypothesis Test } \\
\cline { 4 - 6 } & & $\begin{array}{c}\text { Wald } \\
\text { Chi-Square }\end{array}$ & $\mathrm{df}$ & Sig. \\
\hline Intercept & 69.503 & .8738 & 6327.390 & 1 & .000 \\
\hline $\mathrm{X} 1$ & .020 & .0096 & 4.227 & 1 & .040 \\
\hline $\mathrm{X} 2$ & .001 & .0097 & .017 & 1 & .896 \\
\hline
\end{tabular}

Based on the parameter test as shown in table 19, the teacher performance covariate significantly affect Mathematics learning outcomes by Beta value of 0,020 or $2,0 \%$ because the value of sig $0,040<0,05$. The role of parentscovariate insignificantly affects the Mathematics learning outcomes by Beta value of 0,001 or $0,1 \%$ because the value of sig $0,896>0,05$.

\subsubsection{English Language}

Table 20. Tests of Model Effects

\begin{tabular}{|c|c|c|c|}
\hline \multirow{2}{*}{ Source } & \multicolumn{3}{|c|}{ Type III } \\
\cline { 2 - 4 } & Wald Chi-Square & $\mathrm{df}$ & Sig. \\
\hline (Intercept) & 6177.049 & 1 & .000 \\
\hline $\mathrm{X} 1$ & .254 & 1 & .614 \\
\hline $\mathrm{X} 2$ & 56.802 & 1 & .000 \\
\hline
\end{tabular}

The value of the counted Chi-square 0,254 $<$ Chi-square table 3,841 then $\mathrm{H} 0$ is accepted and $\mathrm{H} 1$ is rejected. This means that teacher performance covariate have no effect on English Language learning outcome. The value of the counted Chi-square 56,802 > Chi-square table 3,841 then $\mathrm{H} 0$ is rejected and H1 is accepted. This means that the role of parents covariate affects the English Language learning outcome.

Based on the parameter test as shown in table 21, The teacher performance covariate insignificantly affect on English learning outcomes by Beta value of -0.005 or $0,5 \%$ because the value of sig $0,614>0,05$. The role of parents covariate significantly affects the English Language learning outcome by Beta value of 0,073 or $7,3 \%$ because of the sig $0,000<0,05$.

Table 21. Parameter Estimates

\begin{tabular}{|c|c|c|c|c|c|}
\hline \multirow[b]{2}{*}{ Parameter } & \multirow[b]{2}{*}{$\mathrm{B}$} & \multirow{2}{*}{$\begin{array}{l}\text { Std. } \\
\text { Error }\end{array}$} & \multicolumn{3}{|c|}{ Hypothesis Test } \\
\hline & & & $\begin{array}{c}\text { Wald } \\
\text { Chi-Square }\end{array}$ & $\mathrm{df}$ & Sig. \\
\hline Intercept & 68.673 & .8738 & 6177.049 & 1 & .000 \\
\hline $\mathrm{X} 1$ & -.005 & .0096 & .254 & 1 & .614 \\
\hline $\mathrm{X} 2$ & .073 & .0097 & 56.802 & 1 & .000 \\
\hline
\end{tabular}

4.7.4. Natural Sciences

Table 22. Tests of Model Effects

\begin{tabular}{|c|c|c|c|}
\hline \multirow{2}{*}{ Source } & \multicolumn{3}{|c|}{ Type III } \\
\cline { 2 - 4 } & Wald Chi-Square & $\mathrm{df}$ & Sig. \\
\hline (Intercept) & 6278.612 & 1 & .000 \\
\hline $\mathrm{X} 1$ & .005 & 1 & .946 \\
\hline $\mathrm{X} 2$ & 8.670 & 1 & .003 \\
\hline
\end{tabular}

The value of the counted Chi-square $0,005<$ Chi-square table 3,841 then $\mathrm{H} 0$ is accepted and $\mathrm{H} 1$ is rejected. This means that teacher performance covariate do not affect the Natural Sciences learning outcomes. The value of the counted Chi-square 8,670 $>$ Chi-square table 3,841 then H0 is rejected and H1 is accepted. This means that the role of parents covariate affect the Natural Sciences learning outcomes.

Table 23. Parameter Estimates

\begin{tabular}{|c|c|c|c|c|c|}
\hline \multirow[b]{2}{*}{ Parameter } & \multirow[b]{2}{*}{ B } & \multirow{2}{*}{$\begin{array}{l}\text { Std. } \\
\text { Error }\end{array}$} & \multicolumn{3}{|c|}{ Hypothesis Test } \\
\hline & & & $\begin{array}{c}\text { Wald } \\
\text { Chi-Square }\end{array}$ & $\mathrm{df}$ & Sig. \\
\hline Intercept & 69.235 & .8738 & 6278.612 & 1 & .000 \\
\hline $\mathrm{X} 1$ & .000 & .0096 & .005 & 1 & .946 \\
\hline $\mathrm{X} 2$ & .028 & .0097 & 8.670 & 1 & .003 \\
\hline
\end{tabular}

Based on the parameter test as shown in table 23, The teacher performance covariate has an insignificant effect on the Natural Sciences learning outcomes by Beta value of 0,000 or $0 \%$ because the value of sig $0,946>0,05$. The role of parents covariate significantly affects the Natural Sciences learning outcome by Beta value of 0,028 or $2,8 \%$ because the value of sig $0,003<0,05$.

\section{Discussion and Conclusions}

The results of the GLZ analysis showed that teacher performance has an effect on Indonesian learning outcomes by $-0,046$ or $4,6 \%$. The correlation between teacher performance and Indonesian Language learning outcome is in accordance with the hypothesis that "There is a 
significant correlation between teacher performance and Indonesian Language learning outcome." Likewise, the role of parents affect Indonesian Language learning outcome by 0,040 or $4,0 \%$. The correlation between role of parents and Indonesian Language learning outcome is in accordance with the hypothesis that "There is a significant correlation between the role of parents and Indonesian Language learning outcome." This is consistent with previous research by Lestari (2016) and Hamalik (2002) that teachers affect student learning outcomes. Similarly, the role of parents in accordance with previous research by Wahyuni (2017) namely the role of parents affect student learning outcome and also the theory Adhim (2004) that the RPM3 (responding, preventing, monitoring, mentoring, and modeling) approach affect student learning outcomes. Patmonodewo (2008) also argued that there are 3 important things that will be achieved when parents and schools work together, which is the parents and children self-concept will increase, children's learning motivation increase, and the children achievements will also increase. Junianto and Wagiran (2013) also stated that teacher performance and parental involvement affect student learning outcomes.

Teacher performance affects the Mathematics learning outcome by 0,020 or $2,0 \%$. The correlation between teacher performance and Mathematics learning outcomes is in accordance with the hypothesis "There is a significant correlation between teacher performance and Mathematics learning outcome." The role of parents has no effect on Mathematics learning outcomes with a value of Beta 0,001 or $0,1 \%$. The correlation between role of parents and mathematics learning outcome is not in accordance with the hypothesis that "There is no significant correlation between the role of parents and mathematics learning outcome." Teacher performance in accordance with previous research by Lestari (2016) and Hamalik (2002) that teachers affects student learning outcome. Supardi (2014) added that teacher performance is clearly visible in learning as seen from student learning outcomes. Similar with Bashir (2014), the school environment has a bigger effect on student Mathematics performance. According to Tataroğlu-Taşdan (2019) to achieve effective teaching, Mathematics teachers need to have a variety of knowledge and skills. It is important for teachers to design and use mathematical descriptions, explanations, and justifications that are accurate so that they can be understood and useful for students in contexts that reflect the their mathematical knowledge when teaching. The role of parents does not fit the theory. This is because the parents' role on Mathematics learning management and motivating children to learn Mathematics is un-optimal because through preliminary studies, researchers found that students do not like Mathematics. Mathematics is a difficult subject for students. Similar with Yigzaw (2019), the parents contribution in improving students' school behavior is low because of the lack of proper training strategies and poor interactions between home and school, and also unoptimal parental monitoring. Bashir (2014) in his research stated that the school environment has a bigger influence on student Mathematics performance than the home environment. Research by Astuti and Rivaie (2013) also suggested that parents have not maximally guided their children to study at home because the parents are busy, thus they do not have time to guide their children, and also economic factor make parents do not be able to provide facilities for learning.

Teacher performance has no effect on English Language learning outcome with a value of Beta $-0,005$ or $0,5 \%$. The correlation between teacher performance and English Language learning outcome is not in accordance with the hypothesis that "There is no significant correlation between teacher performance and English Language learning outcome." The role of parents affect English Language learning outcome by 0,073 or $7,3 \%$. and has a positive correlation. The correlation between the parents and English Language learning outcome in accordance with the hypothesis that "There is a significant correlation between the role of parents and English Language learning outcome." The effect of teacher performance is not in accordance with relevant theories and research. This is because students are less interested in learning English Language subject. Based on preliminary studies researchers found that teachers are unoptimal in the innovation of teaching and learning so students find it difficult to capture the subject matter essence. Yigzaw (2019) in his research found that poor teaching methods, and inadequate school facilities resulted in student school low behavior. Therefore, the lack of facilities makes the teacher performance un-optimal, and this requires teachers' creativity and innovation in Mathematics learning. Weideman dan Albert (2002) revealed that teachers must always make learning innovations so that their teaching performance is maximal. The effect of the role of parentsis in accordance with the theory and research by Epstein (2010) that the role of parents referred to helping children with English Language course at home. Xuesong (2006) claimed that families can affect students' foreign language learning process, both directly by training them to become a good language learners and indirectly by acting as language learning facilitators and teacher collaborators. Cooper and Maloof (1999) stated that students adopt a more positive attitude toward language learning when their parents asking about their foreign language lessons, helping their assignments, and trying to learn languages together with them.

Teacher performance has no effect on Natural Sciences learning outcome with a value of Beta 0,000 or $0 \%$. The correlation between teacher performance and Natural Sciences learning outcome is not in accordance with the hypothesis that "There is no significant correlation between teacher performance and Natural Sciences learning outcome." The role of parents affect the Natural Sciences learning outcome by 0,028 or $2,8 \%$. The correlation between the role of parents and Natural Sciences learning outcome is in accordance with the hypothesis that "There is 
a significant correlation between the role of parents and learning Natural Sciences outcome." In Al-amadi (2018) research, almost 1,200 of the grade 7-12 students were surveyed, $45 \%$ of students said that the role of parents was the most influential factor in learning Natural Sciences compared to around $24 \%$ of the teacher influence. Parents demonstrate an intermediate level of trust in Natural Sciences teachers, helping and supporting children in learning Natural Sciences such as solving problems and helping with tasks.

Based on the results of data analysis and discussion, it can be concluded that: 1) teacher performance significantly influences Indonesian learning outcomes with a Beta value of $-0.046 / 4,6 \%$; and The role of parents also significantly influence the learning outcomes of Indonesian Language with a Beta value of $0.040 / 4,0 \%$; 2) teacher performance significantly influence Mathematics learning outcomes by $0.020 / 2,0 \%$; and The role of non-parents influences Mathematics learning outcomes with a Beta value of $0.001 / 0,1 \%$; 3) teacher performance has no effect on English learning outcomes with a Beta value of $0.005 / 0,5 \%$; and the role of parents significantly influence the learning outcomes of English by $0.073 / 7,3 \%$; 4 ) teacher performance has no effect on science learning outcomes with a Beta value of $0,000 / 0 \%$; and The role of parents significantly influences the science learning outcomes with a Beta value of $0.028 / 2,8 \%$.

Based on the those conclusion, several suggestions are given. First, teacher performance is one of the factors affecting student learning outcomes. Therefore, teacher performance improvement programs need to be promoted as a way for the government to improve student learning outcomes in schools. Teacher performance is influenced by various factors, both internally and externally. According to a research, the need for achievement and teacher values are two important aspects that can improve teacher performance (Suyatno et al., 2019b; Suyatno et al., 2019c). Moreover, teacher performance must always be improved by supervising teacher performance in learning. Supervision of teacher performance are; 1) planning learning by checking the learning administration completion such as syllabus and lesson plans (RPP); 2) the learning implementation by assessing the teacher when teaching in classroom by comparing between the learning steps in the lesson plans or standards set by the government/school with the teacher reality; 3) learning assessment by evaluating the learning process done by the teacher, whether it meets the minimum completeness criteria or not, and the learning success level that the teacher does in the classroom. Second, the role of parents has a significant effect on student learning outcomes. Therefore, parents must increase their role as the first school for their children. The role of parents oriented to the task, process, and development. This means that the school synergizes with students' parents in the learning management.

\section{REFERENCES}

[1] Adhim, F. (2004). Adventures in Parenting: Bagaimana sukses berperan sebagai orang tua yang baik. Yogyakarta: Alenia.

[2] Al-amadi, A. (2018) 'The Role of Family Engagement in Students' Science Learning in Qatari Schools', in The Eurasia Proceedings of Educational \& Social Sciences (EPESS), pp. 142-152.

[3] Astuti, D. and Rivaie, W. (2013) 'Analisis peran orang tua dalam meningkatkan hasil belajar siswa kelas $x$ smk muhammadiyah pontianak', Jurnal Pendidikan Sosiologi dan Humaniora, 4(1).

[4] Bashir, S. (2014) 'A Survey of Influence of Environment as a Motivator on Secondary School Students' Performance in Mathematics in Nigeria', The Eurasia Proceedings of Educational and Social Sciences, 1, pp. 48-51.

[5] Cooper, T. C. \& Maloof, V. M. (1999) 'Parent involvement in teaching elementary-level chinese, japanese, and korean', Journal of Educational Research, 92(3), pp. 176-183. doi: 10.1080/00220679909597593.

[6] Coskun, A. (2016) 'Analyzing Secondary School English as a Foreign Language Students' Affective Features in Terms of Different Variables', Bolu Abant İzzet Baysal Üniversitesi Sosyal Bilimler Enstitüsü Dergisi, 16(2), pp. 205-226. doi: 10.11616/basbed.vi.455264.

[7] Dimyati \& Mudjiono (2013) Belajar dan Pembelajaran. Jakarta: Rineka Cipta.

[8] Epstein, J. L. (2010) 'School/Family/Community Partnership: Caring for The Children We Share'.

[9] Erdem, A. \& N Şimşek (2009) 'İlköğretim okulu yöneticilerinin eğitim öğretime katkı sağlamada öğrenci velilerini okula çekme başarısı', İlköğretim Online, 8(2), pp. 357-378.

[10] Gronlund, L. \& Norman, R. L. (1985) 'Measurement and Evaluation in Teaching', in. New York: MacMillan Publishing Company.

[11] Hamalik, O. (2002) Psikologi Belajar dan Mengajar. Bandung: Sinar Baru Algensindo.

[12] Hendrawati, A. and Prasojo, L. D. (2015) 'Pengaruh Kepemimpinan Transformasional Kepala Sekolah, Motivasi Kerja Guru, dan Budaya Sekolah Terhadap Prestasi Belajar', Jurnal Akuntabilitas Manajemen Pendidikan, 3(2), pp. 141-157. doi: 10.21831/amp.v3i2.6331.

[13] Heyder, A. et al. (2020) 'Teachers' belief that math requires innate ability predicts lower intrinsic motivation among low-achieving students', Learning and Instruction. Elsevier, 65(October 2018). doi: 10.1016/j.learninstruc.2019.101220.

[14] Junianto, D. \& Wagiran (2013) 'Pengaruh Kinerja Mengajar Guru, Keterlibatan Orang Tua, Aktualisasi Diri dan Motivasi Berprestasi Terhadap Prestasi', Jurnal Pendidikan Vokasi, 3(3), pp. 307-319.

[15] Lestari, S. (2016) 'Pengaruh Kepemimpinan Kepala Sekolah 
Dan Kinerja Guru Terhadap Prestasi Siswa', Satya Widya, 32(2), p. 127. doi: 10.24246/j.sw.2016.v32.i2.p127-132.

[16] Makmun, A. S. (2001) Psikologi Kependidikan. Bandung: PT Remaja Rosdakarya.

[17] Menteri Pendidikan dan Kebudayaan Republik Indonesia (2017) Peraturan Menteri Pendidikan dan Kebudayaan Republik Indonesia Nomor 30 tentang Pelibatan Keluarga pada Penyelenggaraan Pendidikan. Jakarta.

[18] Narwoto \& Soeharto (2014) 'Faktor-faktor yang berpengaruh terhadap prestasi belajar teori kejuruan siswa SMK', Jurnal Pendidikan Vokasi, 3(4), pp. 222-233.

[19] Nihat, S. (2012) 'Investigation of parental involvement tasks as predictors of primary students' Turkish, Math, and Science \& Technology Achievement', Egitim Arastirmalari Eurasian Journal of Educational Research, pp. 173-196.

[20] Nyikahadzoyi, M. (2015) 'Teachers' knowledge of the concept of a function: A theoretical framework.', International Journal of Science \& Mathematics Education, 13(2), pp. 261-283.

[21] Patmonodewo, S. (2008) Pendidikan Anak Prasekolah. Jakarta: Rineka Cipta.

[22] Purwanto (2011) Evaluasi Hasil Belajar. Yogyakarta: Pustaka Pelajar.

[23] Purwanto, N. M. (2003) Psikologi Pendidikan. Bandung: PT Remaja Rosdakarya.

[24] Rafsanjani, M. A. (2016) 'Pengaruh Persepsi Keterlibatan Orang Tua Terhadap Hasil Belajar Ekonomi Siswa', Journal of Accounting and Business Education, 2(1), pp. 1-9. doi: 10.26675/jabe.v2i1.6046.

[25] Rosenbusch, M. (1987) Second language learning in Young children. Iowa State University.

[26] Sarwono, J. (2014) Teknik jitu memilih prosedur analisis skripsi. Jakarta: PT Elex Media Komputindo Kompas Gramedia.

[27] Schaefer (2007) Bagaimana mempengaruhi anak. Pegangan praktis bagi orang tua. Jakarta: Dahara Prize.

[28] Siregar, E. dan H. N. (2015) Teori Belajar dan Pembelajaran. Edited by A. Jamaludin. Bogor: Ghalia Indonesia.

[29] Sudjana (2014) Penilaian Hasil Proses Belajar Mengajar. Bandung: Remaja Rosdakarya.

[30] Supardi (2014) Kinerja Guru. Jakarta: Rajagrafindo persada.

[31] Suyatno, Jumintono, Pambudi, D.I., Mardati, A., Wantini (2019a). Strategy of Values Education in Indonesian Education System, International Journal of Instruction, 12(1), pp. 607-624.

[32] Suyatno, Pambudi, D. I., Mardati, A., Wantini, Nuraini, E., and Yoyo. (2019b) 'The education values of Indonesian teachers: Origin, importance, and its impact on their teaching', International Journal of Instruction, 12(3), pp. 633-650. doi: 10.29333/iji.2019.12338a.

[33] Suyatno S., Wantini, W., Baidi, B., \& Amurdawati, G. (2019c) The influence of values and achievement motivation on teacher professionalism at Muhammadiyah 2 high school Yogyakarta, Indonesia, Pedagogika, 133(1), pp. 105-127. doi: $10.15823 /$ p.2019.133.6.

[34] Syah, M. (2003) Psikologi Belajar. Jakarta: PT RajaGrafindo Persada.

[35] Tataroglu-Tasdan, B. (2019) 'Matematik Öğretmenlerinin Matematiksel Tanımlamaları, Açıklamaları ve Doğrulamaları Kullanımı: Samet Örneği', Kuramsal Eğitimbilim, 12(4), pp. 1284-1305. doi: 10.30831/akukeg.478101.

[36] Wahyudi, L., Kuncoro, T. and Dardiri, A. (2018) 'Pengaruh Kinerja Pedagogik Guru Dan Kondisi Lingkungan Terhadap Minat Kerja Dan Dampaknya Pada Hasil Belajar Siswa SMK', 41(1), pp. 55-66.

[37] Wahyuni, R. S. (2017) 'Peran Orangtua Terhadap Prestasi Siswa Kelas 5 Di SD Al-Azhar Syifabudi Pekanbaru', Journal Endurance, 2(1), pp. 6-12. doi: 10.22216/jen.v1i3.1526.

[38] Weideman \& Albert (2002) 'overcoming resistance to innovation: suggestions for encouraging change in language teaching', a journal of language learning, 18, p. 1.

[39] Winkel (1999) Psikologi Pengajaran. Jakarta: PT Grasindo.

[40] Xuesong, G. (2006) 'Strategies used by Chinese parents to support English language learning: Voices of "Elite" University students', RELC Journal, 37(3), pp. 285-298. doi: 10.1177/0033688206071302.

[41] Yang, H. (2017) 'The role of social capital at home and in school in academic achievement: The case of South Korea', Asia Pacific Education Review. Springer Netherlands, 18(3), pp. 373-384. doi: 10.1007/s12564-017-9492-7.

[42] Yigzaw, G. S. (2019) 'The Role of Parents in Improving the Behavior of School's Students in Azena Primary School, Ethiopia', International Journal of Educational Research Review, 4(3), pp. 334-349. doi: 10.24331/ijere.573870. 